\title{
The early-stage comprehensive costs of routine PrEP implementation and scale-up in Zambia
}

\author{
Cheryl Hendrickson ${ }^{1,2,3}$, Lawrence C Long ${ }^{1,2,4}$, Craig van Rensburg ${ }^{1,2}$, Cassidy W Claassen ${ }^{6}$, \\ Mwansa Njelesani ${ }^{7}$, Crispin Moyo $^{8}$, Lloyd Mulenga ${ }^{9}$, Heidi O'Bra ${ }^{5}$, Colin A Russell ${ }^{3}$, Brooke \\ E Nichols ${ }^{1,2,3,4}$
}

1. Health Economics and Epidemiology Research Office, Johannesburg, South Africa; 2. Department of Internal Medicine, School of Clinical Medicine, Faculty of Health Sciences, University of the Witwatersrand, Johannesburg, South Africa; 3. Department of Medical Microbiology, Amsterdam University Medical Center, Amsterdam, the Netherlands; 4. Department of Global Health, School of Public Health, Boston University, Boston, MA, 02118, USA; 5. United States Agency for International Development, Lusaka, Zambia; 6. Center for International Health, Education, and Biosecurity (CIHEB), Institute of Human Virology, University of Maryland School of Medicine, Lusaka, Zambia; 7. USAID DISCOVER-Health, John Snow, Inc. Lusaka, Zambia; 8. EQUIP, Lusaka, Zambia 9. Ministry of Health, Lusaka, Zambia

\begin{abstract}
Introduction: Pre-exposure prophylaxis (PrEP) is effective at preventing HIV infection, but PrEP cost-effectiveness is sensitive to PrEP implementation and program costs. Preliminary studies indicate that, in addition to direct delivery cost, PrEP provision requires substantial demand creation and user support to encourage PrEP initiation and persistence. We estimated the cost of providing PrEP in Zambia through different PrEP delivery models.

Methods: Taking a guidelines-based approach for visits, labs and drugs assuming fidelity to the expanded 2018 Zambian PrEP guidelines, we estimated the annual cost of providing PrEP per client for five delivery models: one focused on key populations (men-who-have-sex-withmen (MSM) and female sex workers (FSW), one on adolescent girls and young women (AGYW), and three integrated programs (operated within the HIV counselling and testing service at primary healthcare centres). Program start-up, provider, and user support costs were based on program expenditure data and number of PrEP sites and clients in 2018. PrEP clinic visit costs were based on micro-costing at two PrEP delivery sites (in 2018 USD).
\end{abstract}

Results: The annual cost per PrEP client varied greatly by program type, from $\$ 394$ (AGYW) to $\$ 760$ in an integrated program. Cost differences were driven largely by volume (i.e. the number of clients initiated/model/site) which impacted the relative costs of program support and technical assistance assigned to each PrEP client. Direct service delivery costs, including staff and overheads, labs and monitoring, drugs and consumables ranged narrowly from \$208217/PrEP-user. Service delivery costs were a key component in the cost of PrEP, representing $36-65 \%$ of total costs. Reductions in service delivery costs per PrEP client are expected with further scale-up.

Conclusions: The results show that, even when integrated into full service delivery models, accessing vulnerable, marginalised populations at substantial risk of HIV infection is likely to cost more than previously estimated due to the programmatic costs involved in community sensitization and user support. Improved data on individual client resource usage (e.g. drugs, labs, visits) and outcomes (e.g. initiation, persistence) is required to get a better understanding of the true resource utilization cost and expected outcomes and annual costs of different PrEP programs in Zambia. 
medRxiv preprint doi: https://doi.org/10.1101/2021.12.18.21268023; this version posted December 19, 2021. The copyright holder for this preprint (which was not certified by peer review) is the author/funder, who has granted medRxiv a license to display the preprint in

It is made available under a CC-BY-NC-ND 4.0 International license .

51

52

53

54

55

56

57

58

59

60

61

62

63

64

65

66

67

68

69

70

71

72

\section{Introduction}

Following several clinical trials and observational studies (1-3), the World Health Organization (WHO) has recommended that pre-exposure prophylaxis (PrEP) be offered to anyone at substantial risk of HIV infection (4). Several low- and middle-income countries (LMICs) have adopted these guidelines and are currently implementing national PrEP programs (5). However, limited data are available to inform the total cost and affordability of these programs, which is crucial for policy decisions around implementation strategies for HIV prevention programs.

Several studies have modelled the cost effectiveness of PrEP provision with mixed results (623); however, they largely focus on direct service delivery costs and many do not take into account routine PrEP program support costs. The costs of PrEP programs implemented in routine care settings in sub-Saharan Africa (SSA) are largely unreported and those that are, have thus far focused primarily on targeting key populations including female sex workers (FSW), men who have sex with men (MSM), and priority populations such as adolescent girls and young women (AGYW). Evidence demonstrating the variations in costs of these different PrEP programs, service delivery strategies, and resource utilization in SSA is limited, with only a few demonstration projects having published the costs of providing PrEP in these settings (24-29).

Estimating the costs of scaling up PrEP programs is complicated by the changing 'populationat-risk' for any given time period. Unlike ART, which is intended as a life-long treatment program under which optimal treatment requires $100 \%$ adherence, PrEP is effective when taken during periods of high risk, meaning that cycling on and off PrEP may be appropriate (30). This complicates analyses of budgetary needs and scale-up costs of PrEP programs, an issue that Zambia is currently facing with national PrEP implementation and scale-up. Zambia, a lower-middle income country in southern Africa with an estimated 48,000 new HIV infections in 2018, is currently investing in scaling up its PrEP program (31). Zambia has adopted daily oral PrEP containing tenofovir and emtricitabine as an additional HIV prevention strategy, recommending PrEP for all HIV-negative persons at high risk of HIV acquisition (32). By September 2018, PrEP was offered in 162 sites across nine of the ten provinces, with 3,626 people at risk of HIV infection initiated on PrEP; one year later, this had increased to 
medRxiv preprint doi: https://doi.org/10.1101/2021.12.18.21268023; this version posted December 19, 2021. The copyright holder for this preprint (which was not certified by peer review) is the author/funder, who has granted medRxiv a license to display the preprint in It is made available under a CC-BY-NC-ND 4.0 International license .

23,327 at 728 sites across all provinces(33). These were largely serodiscordant couples, but also included AGYW ages 15-24 (35\%), FSW (9\%), and MSM (3\%) (34). The Zambian Ministry of Health aims to further expand PrEP services, but has limited information on the cost and budgetary impact of this national scale-up.

We present the results of a costing study of PrEP implementation in Zambia, aiming to provide cost estimates of PrEP provision disaggregated by program type. We also present costs per PrEP-month of effective use, using aggregate PrEP persistence data, and compare that to costs for perfect use.

\section{Methods}

\section{Study Setting}

Zambia's PrEP guidelines stipulate that those eligible for PrEP and identified as being at substantial risk of HIV infection (as defined as engaging in one or more risky activities in the past six months) be offered PrEP (Table 1). We costed three types of service delivery models that offered PrEP to: 1) anyone at risk of HIV infection visiting a primary healthcare facility. These programs had integrated PrEP into their HIV testing and counselling (HCT) services) (integrated; across three implementing partners); 2) AGYW as part of a broad, multicomponent package of evidence-based health, educational and social interventions aimed at reducing new HIV infections (AGYW-focused); and 3) FSW and MSM through tailored, targeted community-based interventions (FSW/MSM-focused). The three integrated models, each led by different implementation partners, were rolled out differently and incurred slightly different program costs. The first model focused on outreach, using trained community health workers to sensitize the community about PrEP and refer those interested in PrEP to the local clinic. The second model focused resources on site readiness through preliminary site assessments, training and community consultations. Additionally, there were several international technical support visits from implementation partners. The third model was based on the Community HIV Epidemic Model (CHEC) of care (35), with costs incurred for community education, mobilization, and PrEP sensitization alongside training of health care workers (HCWs) on KP sensitivity and PrEP service delivery. The AGYW-focused program was integrated as part of the DREAMS program for adolescent girls and young women (36). DREAMS (Determined, Resilient, Empowered, AIDS-free, Mentored and Safe) partnership is 
medRxiv preprint doi: https://doi.org/10.1101/2021.12.18.21268023; this version posted December 19, 2021. The copyright holder for this preprint (which was not certified by peer review) is the author/funder, who has granted medRxiv a license to display the preprint in

It is made available under a CC-BY-NC-ND 4.0 International license .

117 a public-private partnership aimed at reducing rates of HIV among AGYW in highest HIV

118 burden countries. It is largely funded and implemented by the United States Agency for 119 International Development (USAID). Support services in this DREAMS PrEP-provision

120 model included community sensitization and demand creation activities through short-term

121 community mobilisers. A website focused on PrEP for AGYW was also created. PrEP was

122 provided at specialized DREAMS centers that had an integrated community health worker who

123 was trained on PrEP provision. The program also provided continued PrEP-user support using 124 peer navigators. Finally, the FSW- and MSM-focused programs were targeted community125 based demand creation programs with referrals to local facilities for PrEP initiation and follow 126 up. Short-term mobilisers and peer navigators spent time in the local communities to 127 specifically reach FSW and MSM populations, create demand for PrEP refer them for services 128 at the clinics and provide continued support to PrEP clients. A three and a half-day non-clinical 129 training was undertaken to orient non-clinical program staff on PrEP roll-out.

\section{Costs}

132 The costs of the PrEP programs were estimated from the providers' perspective, with data collected in 2018 and reported in 2018 US dollars (USD). Costs collected in Zambian Kwacha were converted to the USD equivalent based on the average exchange rate for 2018 of 10.4988 ZMW to 1 USD (January-December) (37). We used expenditure analysis in estimating financial costs and tracked actual implementation expenses including training, demand creation and technical support. At the facility-level we only included costs directly related to PrEP programming such as counsellor-time, facility space and equipment. We categorized the costs into program costs and direct service delivery costs. Program costs included project start-up costs, training, sensitization as well as provider and user support costs. Direct service delivery costs included clinical personnel, supplies, laboratory tests and drugs (Table 2).

Annualized program start-up, provider, and user support costs were based on program expenditure data and the number of PrEP sites and clients in 2019. Program start-up costs included training (annualized over two years), initial client demand creation activities and communication. Program support costs included recurring costs such as ongoing technical assistance and patient support costs (for example, peer navigators, peer support groups, social media support). We verified costing data via interviews with clinical staff and implementing partners and triangulation with program records. We analyzed costs in Excel 2018 (Microsoft, 
medRxiv preprint doi: https://doi.org/10.1101/2021.12.18.21268023; this version posted December 19,2021 . The copyright holder for this preprint (which was not certified by peer review) is the author/funder, who has granted medRxiv a license to display the preprint in

It is made available under a CC-BY-NC-ND 4.0 International license .

150 Redmond, USA). Ethical approval, as well as a consent process, were not required for this

151 study as this was not human subjects' research, given that only aggregate publicly available

152 program data were used.

153

154 Analysis

155 We estimated the annual cost of providing PrEP services assuming fidelity to the expanded

1562018 Zambian PrEP guidelines for 12-months of PrEP (Table 1). We estimated patient

157 resource use based on these guidelines from the day of PrEP initiation for 12 months,

158 assuming continuous PrEP use for the duration. These direct service delivery costs included

159 drugs, laboratory tests, and clinic visits. Assuming full adherence to guidelines, we then

160 applied the unit costs to the resources expected to be used over the 12-month period by sex

161 and risk group (Table 2).

162

163 Furthermore, we simulated a cohort of 1000 individuals taking PrEP over a 12-month period

164 under two scenarios: 1) all PrEP-clients took PrEP continuously for 12-months and 2) using

165 the actual continuation rates from programmatic PrEP data for visits at months 1, 3, 6, 9 and

16612 for men, women and MSM. Using the population-specific service delivery costs, we

167 determined a total cost per month based on these continuation rates. We calculated the

168 cumulative number of protected months for each visit over a 12-month period and, using this,

169 calculated the cost of PrEP per person-month effectively covered on PrEP. 

Year 1 (at least 6 visits)

Year 2 (at least 4 visits)

\begin{tabular}{|c|c|c|c|c|c|c|c|c|c|c|}
\hline & \multirow{2}{*}{$\begin{array}{l}\text { Initial visit and } \\
\text { PrEP initiation }\end{array}$} & \multicolumn{9}{|c|}{ Follow-up months } \\
\hline & & 1 & 3 & 6 & 9 & 12 & 15 & 18 & 21 & 24 \\
\hline Confirmation of HIV-negative status & $\mathrm{X}$ & $\mathrm{X}$ & $\mathrm{X}$ & $\mathrm{X}$ & $\mathrm{X}$ & $\mathrm{x}$ & $\mathrm{X}$ & $\mathrm{x}$ & $\mathrm{x}$ & $\mathrm{x}$ \\
\hline Serum Creatinine & $\mathrm{x}$ & $\mathrm{X}$ & $\mathrm{X}$ & $\mathrm{X}$ & $\mathrm{X}$ & $\mathrm{x}$ & & & & $\mathrm{x}$ \\
\hline Hepatitis B surface antigen & $\mathrm{x}$ & & & $\mathrm{X}$ & & & & & & \\
\hline Hepatitis $\mathrm{C}$ antibody* & $\mathrm{x}$ & & & $\mathrm{x}$ & & & & & & \\
\hline Pregnancy testing** & $\mathrm{x}$ & & & & & & & & & \\
\hline Rapid Plasma Reagin (RPR) & $\mathrm{x}$ & & & $\mathrm{X}$ & & & & $\mathrm{x}$ & & \\
\hline $\begin{array}{l}\text { Other screening for sexually } \\
\text { transmitted infections (STIs) }\end{array}$ & $\mathrm{x}$ & & $\mathrm{X}$ & $\mathrm{X}$ & $\mathrm{X}$ & $\mathrm{x}$ & $\mathrm{x}$ & $\mathrm{x}$ & $\mathrm{x}$ & $\mathrm{x}$ \\
\hline Alanine Transaminase (ALT) & $\mathrm{x}$ & & & $\mathrm{X}$ & & & & & & $\mathrm{X}$ \\
\hline
\end{tabular}

*Included for men-who-have-sex-with-men MSM only

**Included for women only 
Table 2: Cost methods and unit costs for direct service delivery costing

\begin{tabular}{|c|c|c|c|c|c|c|}
\hline Resource & Method for estimating cost & Item & Unit & $\begin{array}{l}\text { Cost } \\
\text { (ZMW) }\end{array}$ & $\begin{array}{l}\text { Cost } \\
\text { (USD) }\end{array}$ & Source \\
\hline Drugs & $\begin{array}{l}\text { Drug costs were calculated by the drugs prescribed, the dosage } \\
\text { required and the duration the drug would be taken for (in this case, } \\
12 \text { months). According to guidelines, PrEP-clients are required to } \\
\text { pick up monthly drug supplies for the first twelve months. The } \\
\text { published national drug unit costs were applied to determine total } \\
\text { drug cost per client. }\end{array}$ & $\begin{array}{l}\text { Emtricitabine } \\
+ \text { Tenofovir }\end{array}$ & Tablet & 2.51 & 0.22 & $\begin{array}{l}\text { Medical Stores } \\
\text { Limited (MSL) } \\
\text { Catalogue 2016 } \\
\text { [prices } \\
\text { unchanged 2016- } \\
\text { 2018] }\end{array}$ \\
\hline \multirow{7}{*}{ Laboratory tests } & \multirow{7}{*}{$\begin{array}{l}\text { The number of tests performed per PrEP-client for the study period } \\
\text { was extrapolated based the Zambian guidelines and target } \\
\text { population type. According to the Zambia guidelines, all PrEP- } \\
\text { users undergo the same monitoring labs, with the exception of the } \\
\text { addition of pregnancy testing for women and Hepatitis C antibody } \\
\text { testing for MSM; for the purposes of this analysis, we assumed that } \\
\text { all users received all required lab tests at each visit. Since the cost } \\
\text { of public sector laboratory tests are not available in Zambia, we } \\
\text { estimated public sector laboratory costs by adjusting the } 2018 \\
\text { South African National Health Laboratory Services pricelists. } \\
\text { Using the published cost of an HIV viral load test performed at a } \\
\text { central government laboratory in Zambia, we calculated adjusted } \\
\text { prices for the applicable laboratory tests for PrEP in Zambia. }\end{array}$} & Creatinine & Test & 24.07 & 2.29 & \multirow{7}{*}{$\begin{array}{l}\text { South Africa's } \\
2018 \text { NHLS } \\
\text { pricelist, adjusted } \\
\text { using ratio of } \\
\text { South Africa } \\
\text { public sector } \\
\text { viral load price } \\
\text { to Zambia's } \\
\text { public sector } \\
\text { viral load price } \\
\text { as reported in } \\
\text { Nichols et al. } \\
2020 \text { (39) } \\
\text { (no public } \\
\text { laboratory price } \\
\text { list available for } \\
\text { general non-viral } \\
\text { load tests) }\end{array}$} \\
\hline & & ALT & Test & 36.03 & 3.43 & \\
\hline & & HBsAg & Test & 99.85 & 9.51 & \\
\hline & & RPR/RST & Test & 15.59 & 1.49 & \\
\hline & & Pregnancy* & Test & 67.33 & 6.41 & \\
\hline & & STIs & Test & 55.85 & 5.32 & \\
\hline & & $\begin{array}{l}\text { Hep C } \\
\text { antibody** }\end{array}$ & Test & 99.85 & 9.51 & \\
\hline \multirow{2}{*}{ Clinic visit costs $* * *$} & \multirow{2}{*}{$\begin{array}{l}\text { We costed three different types of visits: initiation, } \\
\text { monitoring/follow-up and drug pick-up visits. These PrEP clinic } \\
\text { visit costs were based on micro-costing at two PrEP delivery sites } \\
\text { in Lusaka and include staff time, consumables (including HIV test } \\
\text { and condoms), and overheads (equipment, space, water, effluent, } \\
\text { and electricity). }\end{array}$} & $\begin{array}{l}\text { PrEP initiation } \\
\text { visit }\end{array}$ & Visit & 42.36 & 4.03 & \multirow{2}{*}{$\begin{array}{l}\text { MSL catalogue, } \\
2016 \text { USD } \\
\text { [prices } \\
\text { unchanged 2016- } \\
2018 \text { ] }\end{array}$} \\
\hline & & $\begin{array}{l}\text { PrEP follow- } \\
\text { up visit at } \\
\text { month } 1\end{array}$ & Visit & 39.57 & 3.77 & \\
\hline
\end{tabular}


Staff time required for each visit type by staff cadre was estimated using information provided by healthcare workers and

implementing partners. The staff cost per minute was calculated using Ministry of Health salaries for each respective cadre of staff involved in PrEP delivery. Clinical staff salaries were obtained from the published list of public sector salaries for that cadre.

We estimated the consumables, such as needles and gloves, used per visit type through discussion with the staff and mapping what activities occur during a visit at the two clinics in Lusaka. Unit costs of consumables were obtained from supplier price lists (MSL catalogue, 2016 USD [prices unchanged 2016-2018]).

Equipment and overhead costs were estimated across ten healthcare facilities in two provinces (Central and Copperbelt) through a separate project aimed at costing standard ART visits (31). These costs then applied to our study as ART patients frequent the same spaces and spent similar amount of time in a facility as with PrEP visits.

\begin{tabular}{|c|c|c|c|c|}
\hline $\begin{array}{l}\text { PrEP follow- } \\
\text { up visits at } \\
\text { months } 3,9 \\
\text { and } 12 \\
\end{array}$ & Visit & 40.37 & 3.84 & $\begin{array}{l}\text { Zambia } \mathrm{MOH} \\
\text { salary scales }\end{array}$ \\
\hline $\begin{array}{l}\text { PrEP follow- } \\
\text { up visit at } \\
\text { month } 6\end{array}$ & Visit & 41.96 & 4.00 & \\
\hline $\begin{array}{l}\text { Pharmacy } \\
\text { pick-up }\end{array}$ & Visit & 6.19 & 0.59 & \\
\hline
\end{tabular}

*For women only

**For men-who-have-sex-with-men only

***Visits include staff time, consumables, and overheads (equipment, shared space, dedicated space and facility-level overheads). Consumables differ by visit as per guidelines. Consumables include the HIV test and condoms as appropriate. 
medRxiv preprint doi: https://doi.org/10.1101/2021.12.18.21268023; this version posted December 19, 2021. The copyright holder for this preprint (which was not certified by peer review) is the author/funder, who has granted medRxiv a license to display the preprint in

It is made available under a CC-BY-NC-ND 4.0 International license .

\section{Results}

177

178 The number of PrEP-clients and sites varied across programs, with the average number of

179 PrEP-clients per site ranging from 3.6 in the Integrated 1 program and almost 70 in the AGYW

180 program (Table 3). Start-up costs per site ranged from just over $\$ 400$ for the Integrated 3

181 program to over $\$ 5000$ for the AGYW program. However, this cost difference between the two

182 programs disappeared when taking into account the number of PrEP-clients per site, with both

183 programs costing $\$ 73$ per PrEP-client per site. The Integrated 1 site incurred the largest start-

184 up costs per PrEP-client per site at \$230, while the Integrated 2 was the least costly at \$26 per

185 PrEP-client per site.

186

187 Recurrent costs per PrEP-client also varied by program, driven by the differences in 188 programmatic support costs. These ranged from $\$ 113$ for the AGYW program to $\$ 377$ for the 189 third integrated program. Direct service delivery costs did not vary greatly, with the variation 190 due to the different monitoring laboratory tests guidelines require for each target population.

191 The proportion of recurrent costs attributable to programmatic support costs ranged from just over a third (35\%) for the AGYW-focused program to almost two-thirds for the third integrated program (64\%), with the two priority population focused programs spending a lower proportion of these costs on programmatic support costs than the integrated programs (Figure 1). The drug costs carried the highest proportion of the service delivery costs at about $40 \%$, followed by monitoring labs at about a third of the cost. However, when compared to the costs of drugs and labs as a proportion of the entire recurrent program costs, this fell to between 15$27 \%$ and $11-21 \%$ respectively.

When taking the average number of PrEP-clients initiated per site into account, and combining program start-up and recurrent support costs and assuming 12 months of continuous PrEP-use, the annual cost per PrEP initiate in 2018 varied greatly by program type, with two of the integrated programs being most costly at $\$ 760$ and $\$ 660$ per PrEP-initiate. The FSW/MSMtargeted program and third integrated program cost $\$ 425$ and $\$ 406$ per PrEP initiate respectively. The least costly program per PrEP initiate, considering start-up costs, number of sites and site volume was the AGYW program at \$394 per PrEP initiate. These cost differences were driven largely by the differences in the average number of PrEP-clients initiated per site 
medRxiv preprint doi: https://doi.org/10.1101/2021.12.18.21268023; this version posted December 19, 2021. The copyright holder for this preprint (which was not certified by peer review) is the author/funder, who has granted medRxiv a license to display the preprint in It is made available under a CC-BY-NC-ND 4.0 International license .

208

209

210

211 Comparing two simulation scenarios, one with perfect PrEP persistence and the other using

212 PrEP continuation data from Zambia, we see that the cost of PrEP provision per person-

213 month effectively covered on PrEP decreases over time for all groups under both scenarios

214 (Figure 2). However, this decrease is less substantial when there is imperfect persistence. For

215

216

217

218

219 continuous PrEP use was $\$ 63$, almost double that of the AGYW-focused program at $\$ 33$. example, the cost of PrEP provision per person month among MSM is 76\% greater at 12 months when using actual data on persistence in that risk group as compared to assuming perfect persistence. For women, this difference is smaller at 27\% (\$20 per person at 12 months with actual persistence rates versus $\$ 16$ for perfect persistence). The smallest difference is among men with an $18 \%$ greater cost of PrEP provision per person month at 12 months.

\section{Figure 1: Proportion of total annual cost per PrEP-client by cost inputs}

across each program. The total cost per PrEP-client per person-month, assuming 12 months of
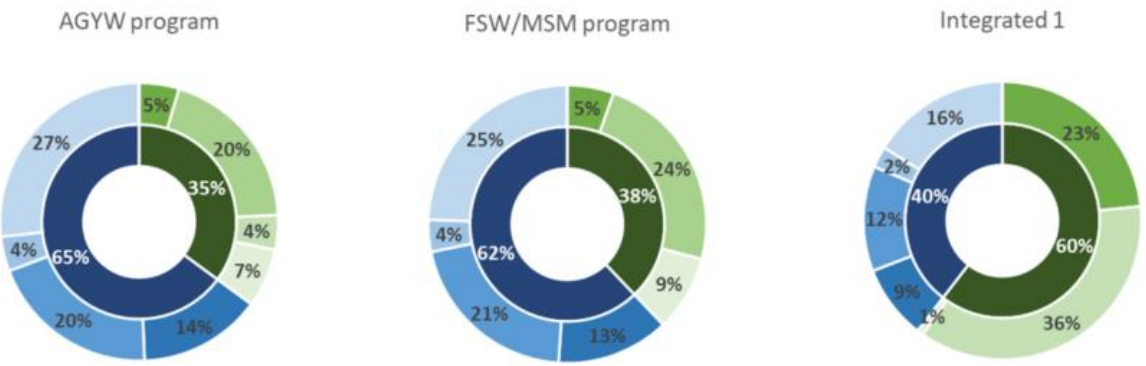

Integrated 2
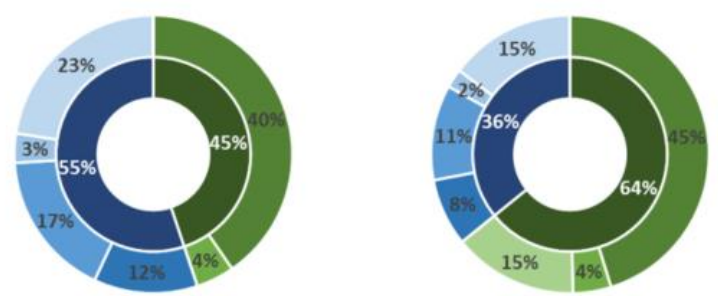

Direct service delivery costs

Programmatic support costs

Staff \& Overheads

Technical support

Training

PrEP user support

PrEP provider support

PrEP Drugs

Demand creation communication 
225 Table 3: 2018 costs of PrEP-provision according to Zambian guidelines (USD)

\begin{tabular}{|c|c|c|c|c|c|}
\hline & \multicolumn{5}{|c|}{ Program Type } \\
\hline & AGYW & FSW/MSM & Integrated 1 & Integrated 2 & Integrated 3 \\
\hline Number of PrEP clients initiated in program & 908 & 213 & 322 & 214 & 148 \\
\hline Number of total sites & 13 & 4 & 90 & 4 & 27 \\
\hline Average number of PrEP-clients/site & 69.8 & 53.3 & 3.6 & 53.5 & 5.5 \\
\hline \multicolumn{6}{|l|}{ Start-up costs/site (2018) } \\
\hline Community sensitization/consultation & 0 & 0 & 156 & 654 & 242 \\
\hline Training & 3979 & 2844 & 668 & 308 & 160 \\
\hline Site assessments & 0 & 0 & 0 & 422 & 0 \\
\hline Equipment & 1149 & 1149 & 0 & 0 & 0 \\
\hline Average cost of start-up/site & 5128 & 3992 & 824 & 1384 & 403 \\
\hline Average cost of start-up/site/PrEP-client & 73 & 75 & 230 & 26 & 73 \\
\hline \multicolumn{6}{|l|}{ Recurrent costs } \\
\hline \multicolumn{6}{|l|}{ Programmatic support costs/PrEP-client } \\
\hline Technical support & 0 & 0 & 0 & 154 & 265 \\
\hline Training & 15 & 19 & 124 & 17 & 26 \\
\hline PrEP user support & 63 & 83 & 0 & 0 & 85 \\
\hline PrEP provider support & 13 & 0 & 193 & 0 & 0 \\
\hline Demand creation communication & 22 & 31 & 4 & 0 & 0 \\
\hline Average programmatic support costs/PrEP-client (\% of recurrent costs) & $113(35 \%)$ & $133(38 \%)$ & $321(61 \%)$ & $171(45 \%)$ & 377 (64\%) \\
\hline \multicolumn{6}{|l|}{ Direct service delivery costs/PrEP-client } \\
\hline Staff \& Overheads & 46 & 46 & 46 & 46 & 46 \\
\hline Labs and monitoring & 64 & 73 & 65 & 65 & 65 \\
\hline Consumables & 13 & 13 & 13 & 13 & 13 \\
\hline PrEP Drugs & 86 & 86 & 86 & 86 & 86 \\
\hline Average direct service delivery costs/PrEP-client (\% of recurrent costs) & $208(65 \%)$ & $217(62 \%)$ & $209(39 \%)$ & 209 (55\%) & $209(36 \%)$ \\
\hline Total recurrent cost/PrEP-client/year & 320 & 350 & 530 & 381 & 586 \\
\hline Total average cost/PrEP-client/year & 394 & 425 & 760 & 406 & 659 \\
\hline Total cost/person-month* & 33 & 35 & 63 & 34 & 55 \\
\hline
\end{tabular}


medRxiv preprint doi: https://doi.org/10.1101/2021.12.18.21268023; this version posted December 19, 2021. The copyright holder for this preprint (which was not certified by peer review) is the author/funder, who has granted medRxiv a license to display the preprint in It is made available under a CC-BY-NC-ND 4.0 International license .

Figure 2: Cost of PrEP provision per person-month effectively covered on PrEP, using aggregate persistence data from partner data (USD) (Service delivery costs only)

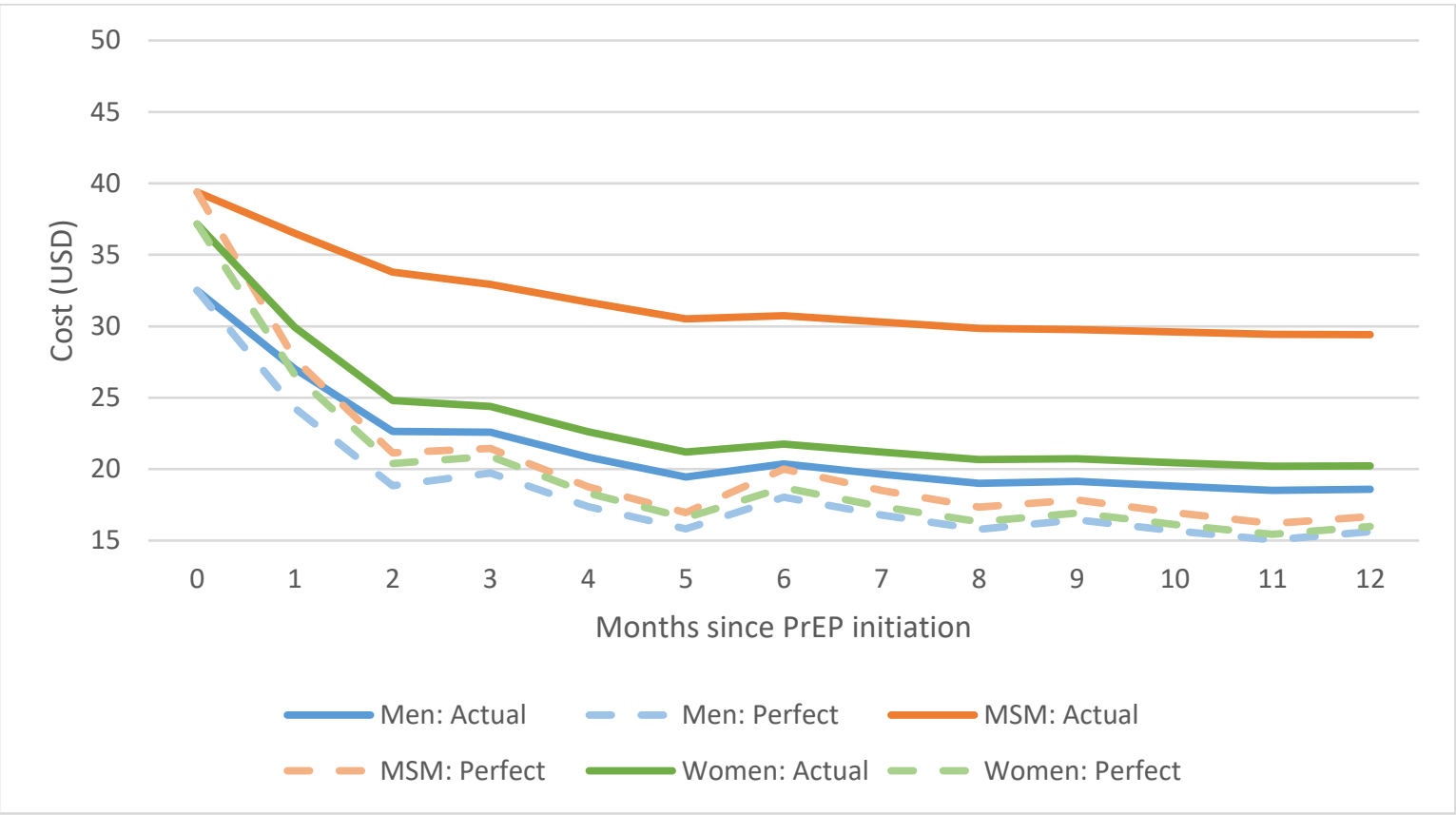

\section{Discussion}

234 Modelling studies for PrEP in SSA indicate that PrEP can be cost effective when targeted to specific high-risk groups (40); however, most models have not used data from real-world implementation settings. To date only a few studies have reported the cost of providing PrEP to priority populations in SSA using data from demonstration projects or routine implementation. In this study, we address this gap and add to the small but growing PrEP cost literature by describing the guideline-based costs of PrEP service delivery in the context of a generalized epidemic in an LMIC. We estimated that the overall average cost to provide PrEP to an at-risk individual for a full 12 months in Zambia ranged from $\$ 394$ to $\$ 760$, or $\$ 33$ to $\$ 63$

242 per person-month on PrEP. This varied by the different service delivery models, with programs

243 focused on reaching priority populations (AGYW, FSW/MSM) generally costing less than

244 those integrated into existing healthcare facilities, when taking into consideration the average 245 number of PrEP-clients per site. Our analysis shows that recurrent PrEP-provision costs are variable depending on the type of program; however, we estimate that the costs are between

$247 \$ 320$ and \$586 per PrEP initiate depending on the program type. These costs are based solely on the Zambian PrEP policy, which assumes that all patients were treated precisely according 
medRxiv preprint doi: https://doi.org/10.1101/2021.12.18.21268023; this version posted December 19, 2021. The copyright holder for this preprint (which was not certified by peer review) is the author/funder, who has granted medRxiv a license to display the preprint in

It is made available under a CC-BY-NC-ND 4.0 International license .

to these guidelines, with no variation among patients based on condition, logistical challenges, or other potential variants.

The costs of PrEP provision we report in this study, ranging from $\$ 394$ to $\$ 760$ are generally higher than those documented in other costing studies from the region. In Kenya and Uganda, the incremental cost of providing PrEP to serodiscordant couples under study settings was just over $\$ 305$ and $\$ 408$ respectively $(25,27)$, while in South Africa PrEP provision cost about $\$ 127$ per year for FSW (24). A study in Zimbabwe reported the cost per PrEP client initiated as $\$ 238$ while another study in Kenya reported an overall cost of $\$ 256(28,41)$. Compared to our calculated costs per person-month, ranging from $\$ 33$ to $\$ 63$, other studies were also lower at \$26.52 under study settings or \$16.54 under MOH scenario and \$21.32 and \$28.92 study, $\$ 14.52$ for adolescent girls and young women $(29,42,43)$. One possible reason for these differing results are the relatively low PrEP client volumes in these programs compared to those reported in other studies, which ranged from 219 to almost 5000. In Kenya, authors report that the cost per client-month of PrEP dispensed is reduced substantially if PrEP delivery is scaled up. This is supported in other HIV scale-up studies that have demonstrated that early implementation costs are greater per patient served ("U-shaped incremental cost curve") (4446). Understanding where we are on the U-shaped curve will assist with planning and to ensure programs are adequately resourced. Similar to HIV treatment programs focusing on hard-toreach key populations, targeted PrEP programs require substantial investment in order to establish and maintain successful programs (47-50). More intensive programmatic inputs and larger PrEP-user volumes are required per site for the key population-focused programs to reach the minimum cost/user; however, this investment may be necessary to effectively reach these groups, especially as more than half of all new HIV infections were among key populations in 2018 , despite being a minority of the overall population (51).

It should also be noted that the start-up cost of scaling up any of these programs nationally likely exceeds the simple multiplication of start-up costs and number of sites. Particularly for the integrated approach, many of the sites that have been reached to date have been relatively easy to reach. The cost to scale-up to all facilities may therefore start to increase once smaller health facilities that serve fewer patients are reached (the other side of the U-shaped incremental cost curve), with additional travel and staff costs to get these sites started (52). There are now more than 1500 health facilities in Zambia that provide ART services (e.g. these 
medRxiv preprint doi: https://doi.org/10.1101/2021.12.18.21268023; this version posted December 19, 2021. The copyright holder for this preprint (which was not certified by peer review) is the author/funder, who has granted medRxiv a license to display the preprint in

It is made available under a CC-BY-NC-ND 4.0 International license .

could potentially also all provide PrEP services), of which $24 \%$ provide service to $80 \%$ of patients, so an effort to scale-up PrEP to all facilities may be cost-prohibitive.

Using PrEP persistence data from Zambia to simulate the cost of PrEP provision over time, we observe that low persistence results in higher costs per PrEP-client, up to 76\%. Therefore, understanding PrEP persistence in the population is key to planning and budgeting. Our data show that it is costly to initiate someone on PrEP who only persists on PrEP for a few months. This does not necessarily mean that a PrEP program is not cost-effective; it just means that this low-usage, or in-and-out cycling, needs to be accounted for when planning PrEP provision and program scale-up. These costs vary with the duration of at-risk periods when PrEP is required - longer periods on PrEP require more visits and medications resulting in high costs of continual PrEP use per year per PrEP-client, though lower per month costs. Preliminary research has shown that, despite heterogeneity within sub-groups of PrEP clients, PrEP persistence in Zambia is low, with retention at three months only $27 \%$ in one study $(33,34)$. This means that the cost per initiate will likely decline rapidly for a given PrEP initiation cohort. Furthermore, the cost per PrEP initiate may be lower depending on how many carry-over PrEP clients come from 2018 into 2019.

This analysis is subject to a number of limitations. First, we relied on implementing partners and provider reports and some resource use may not have been recorded. We were unable to directly observe time spent for PrEP alone from staff time on other primary care and relied on provider recall and estimates to determine time per visit. This may mean our staff cost estimates are lower than would be expected in a low HIV prevalence setting or where care is not integrated. We also excluded salary costs of ancillary implementing partner staff who were involved in PrEP-program planning as they were reported inconsistently across partners. Including these costs would further increase this cost per PrEP client served. These lowest cost thresholds will not apply to truly integrated models where capacity and resources are shared. Furthermore, this analysis does not investigate the effect that changes in integration and standardization would have on the cost of PrEP provision across different clinic sizes. This is an important factor when thinking about PrEP provision to small or more rural clinics where high PrEP-user volumes may not be achievable. Ensuring access, however, even in remote or low-volume facilities is important to ensure equitable PrEP access, and costs associated with a lower PrEP client volume should be planned for. As this analysis is based on national guidelines and does not include patient or program outcomes, we are not making any 
medRxiv preprint doi: https://doi.org/10.1101/2021.12.18.21268023; this version posted December 19,2021 . The copyright holder for this
preprint (which was not certified by peer review) is the author/funder, who has granted medRxiv a license to display the preprint in It is made available under a CC-BY-NC-ND 4.0 International license.

316 conclusions comparing the effectiveness of the various models, but are providing budgetary

317 information only. Further costing work is needed to elucidate the effect of PrEP persistence on

318 the overall costs of PrEP provision. Despite these limitations, this study provides a robust

319 estimate of the costs of PrEP provision under three different service delivery models intended

320 to guide future scale-up. This information will support budgeting and financial planning for

321 PrEP services as Zambia scales up HIV prevention and access to services to achieve national

322 and international targets.

323

\section{Conclusions}

325

326 Given finite resources, methods to ensure low incremental costs for PrEP provision are

327 important. This work demonstrates that the routine implementation and service delivery of

328 PrEP may be more costly than modelling and early demonstration projects indicated. In

329 addition to direct delivery cost, PrEP programs incur substantial costs for demand creation and

330 PrEP-user support. The costs involved in these activities to reach key and priority populations

331 should not be discounted when budgeting for PrEP program scale-up. 
medRxiv preprint doi: https://doi.org/10.1101/2021.12.18.21268023; this version posted December 19,2021 . The copyright holder for this preprint (which was not certified by peer review) is the author/funder, who has granted medRxiv a license to display the preprint in It is made available under a CC-BY-NC-ND 4.0 International license.

\section{Competing interests}

$334 \mathrm{CH}$, LL, and BEN report grants from United States Agency for International Development

335 (USAID), during the conduct of the study. All other authors have no competing interests.

\section{Authors' contributions}

$\mathrm{CH}$ and $\mathrm{BEN}$ were responsible for the initial concept for the paper

LCL, CvR, HO, CWC, MN, CM, LM, CAR were responsible for critical input into development of the paper

$\mathrm{CH}$ and $\mathrm{BEN}$ wrote the first draft of the manuscript

LCL, CvR, HO, CWC, MN, CM, LM, CAR contributed to the writing of the manuscript

All authors reviewed and approved the final draft of the manuscript

\section{Acknowledgements}

354 LCL and BEN). Research reported in this publication was also supported by the Fogarty

355 International Center and National Institute of Mental Health through the National Institutes of 356 Health award number D43 TW010543 (to CH) and K01MH119923 (LCL). The funders had

357 no role in study design, data collection and analysis, decision to publish, or preparation of the 358 manuscript. The authors' views expressed in this publication do not necessarily reflect the 359 views of USAID or the US Government. 
medRxiv preprint doi: https://doi.org/10.1101/2021.12.18.21268023; this version posted December 19, 2021. The copyright holder for this preprint (which was not certified by peer review) is the author/funder, who has granted medRxiv a license to display the preprint in It is made available under a CC-BY-NC-ND 4.0 International license .

\section{References}

1. Fonner VA, Dalglish SL, Kennedy CE, Baggaley R, O'Reilly KR, Koechlin FM, et al. Effectiveness and safety of oral HIV preexposure prophylaxis for all populations. Aids. 2016;30(12):1973-83.

2. Baeten JM, Donnell D, Mugo NR, Ndase P, Thomas KK, Campbell JD, et al. Single-agent tenofovir versus combination emtricitabine plus tenofovir for preexposure prophylaxis for HIV-1 acquisition: an update of data from a randomised, double-blind, phase 3 trial. The Lancet Infectious diseases. 2014;14(11):1055-64.

3. Wilton J, Senn H, Sharma M, Tan DH. Pre-exposure prophylaxis for sexually-acquired HIV risk management: a review. HIV AIDS (Auckl). 2015;7:12536.

4. World Health Organisation. Guideline on when to start antiretroviral therapy and on pre-exposure prophylaxis for HIV. 2015.

5. PrEPWatch. Where do you fit on the map? [Available from: https://www.prepwatch.org/.

6. Gomez GB, Borquez A, Case KK, Wheelock A, Vassall A, Hankins C. The cost and impact of scaling up pre-exposure prophylaxis for HIV prevention: a systematic review of cost-effectiveness modelling studies. PLoS medicine. 2013;10(3):e1001401.

7. Anderson SJ, Cherutich P, Kilonzo N, Cremin I, Fecht D, Kimanga D, et al. Maximising the effect of combination HIV prevention through prioritisation of the people and places in greatest need: a modelling study. Lancet (London, England). 2014;384(9939):249-56.

8. Cambiano V, Miners A, Dunn D, McCormack S, Ong KJ, Gill ON, et al. Costeffectiveness of pre-exposure prophylaxis for HIV prevention in men who have sex with men in the UK: a modelling study and health economic evaluation. The Lancet Infectious diseases. 2018;18(1):85-94.

9. Cremin I, McKinnon L, Kimani J, Cherutich P, Gakii G, Muriuki F, et al. PrEP for key populations in combination HIV prevention in Nairobi: a mathematical modelling study. The lancet HIV. 2017;4(5):e214-e22.

10. Hallett TB, Baeten JM, Heffron R, Barnabas R, de Bruyn G, Cremin I, et al. Optimal uses of antiretrovirals for prevention in HIV-1 serodiscordant heterosexual couples in South Africa: a modelling study. PLoS medicine. 2011;8(11):e1001123.

11. Mitchell KM, Lepine A, Terris-Prestholt F, Torpey K, Khamofu H, Folayan $\mathrm{MO}$, et al. Modelling the impact and cost-effectiveness of combination prevention amongst HIV serodiscordant couples in Nigeria. Aids. 2015;29(15):2035-44. 
medRxiv preprint doi: https://doi.org/10.1101/2021.12.18.21268023; this version posted December 19, 2021. The copyright holder for this preprint (which was not certified by peer review) is the author/funder, who has granted medRxiv a license to display the preprint in It is made available under a CC-BY-NC-ND 4.0 International license .

400

401

402

403

404

405

406

407

408

409

410

411

412

413

414

415

416

417

418

419

420

421

422

423

424

425

426

427

428

429

430

431

432

433

434

435

436

437

438

439

12. Nichols BE, Baltussen R, van Dijk JH, Thuma PE, Nouwen JL, Boucher CA, et al. Cost-effectiveness of PrEP in HIV/AIDS control in Zambia: a stochastic league approach. J Acquir Immune Defic Syndr. 2014;66(2):221-8.

13. Nichols BE, Boucher CA, van Dijk JH, Thuma PE, Nouwen JL, Baltussen R, et al. Cost-effectiveness of pre-exposure prophylaxis (PrEP) in preventing HIV-1 infections in rural Zambia: a modeling study. PLoS One. 2013;8(3):e59549.

14. Pretorius C, Stover J, Bollinger L, Bacaer N, Williams B. Evaluating the costeffectiveness of pre-exposure prophylaxis (PrEP) and its impact on HIV-1 transmission in South Africa. PLoS One. 2010;5(11):e13646.

15. Price JT, Wheeler SB, Stranix-Chibanda L, Hosek SG, Watts DH, Siberry GK, et al. Cost-Effectiveness of Pre-exposure HIV Prophylaxis During Pregnancy and Breastfeeding in Sub-Saharan Africa. J Acquir Immune Defic Syndr. 2016;72 Suppl 2:S145-53.

16. Alistar SS, Grant PM, Bendavid E. Comparative effectiveness and costeffectiveness of antiretroviral therapy and pre-exposure prophylaxis for HIV prevention in South Africa. BMC medicine. 2014;12:46.

17. Cremin I, Morales F, Jewell BL, O'Reilly KR, Hallett TB. Seasonal PrEP for partners of migrant miners in southern Mozambique: a highly focused PrEP intervention. Journal of the International AIDS Society. 2015;18(4 Suppl 3):19946.

18. Jamieson L, Gomez GB, Rebe K, Brown B, Subedar H, Jenkins S, et al. The impact of self-selection based on HIV risk on the cost-effectiveness of preexposure prophylaxis in South Africa. Aids. 2020.

19. Nichols BE, Boucher CAB, van der Valk M, Rijnders BJA, van de Vijver D. Cost-effectiveness analysis of pre-exposure prophylaxis for HIV-1 prevention in the Netherlands: a mathematical modelling study. The Lancet Infectious diseases. 2016;16(12):1423-9.

20. Phillips A, Cambiano V, Johnson L, Nakagawa F, Homan R, Meyer-Rath G, et al. Potential impact and cost-effectiveness of condomless-sex-concentrated PrEP in KwaZulu-Natal accounting for drug resistance. The Journal of infectious diseases. 2019.

21. Quaife M, Terris-Prestholt F, Eakle R, Cabrera Escobar MA, KilbourneBrook M, Mvundura $M$, et al. The cost-effectiveness of multi-purpose HIV and pregnancy prevention technologies in South Africa. Journal of the International AIDS Society. 2018;21(3).

22. van Vliet MM, Hendrickson C, Nichols BE, Boucher CA, Peters RP, van de Vijver DA. Epidemiological impact and cost-effectiveness of providing longacting pre-exposure prophylaxis to injectable contraceptive users for HIV prevention in South Africa: a modelling study. Journal of the International AIDS Society. 2019;22(12):e25427. 
medRxiv preprint doi: https://doi.org/10.1101/2021.12.18.21268023; this version posted December 19, 2021. The copyright holder for this preprint (which was not certified by peer review) is the author/funder, who has granted medRxiv a license to display the preprint in It is made available under a CC-BY-NC-ND 4.0 International license .

440

441

442

443

444

445

446

447

448

449

450

451

452

453

454

455

456

457

458

459

460

461

462

463

464

465

466

467

468

469

470

471

472

473

474

475

476

477

478

23. Walensky RP, Jacobsen MM, Bekker LG, Parker RA, Wood R, Resch SC, et al. Potential Clinical and Economic Value of Long-Acting Preexposure Prophylaxis for South African Women at High-Risk for HIV Infection. The Journal of infectious diseases. 2016;213(10):1523-31.

24. Eakle R, Gomez GB, Naicker N, Bothma R, Mbogua J, Cabrera Escobar MA, et al. HIV pre-exposure prophylaxis and early antiretroviral treatment among female sex workers in South Africa: Results from a prospective observational demonstration project. PLoS medicine. 2017;14(11):e1002444.

25. Irungu EM, Sharma M, Maronga C, Mugo N, Ngure K, Celum C, et al. The Incremental Cost of Delivering PrEP as a Bridge to ART for HIV Serodiscordant Couples in Public HIV Care Clinics in Kenya. AIDS research and treatment. 2019;2019:4170615.

26. Roberts DA, Barnabas RV, Abuna F, Lagat H, Kinuthia J, Pintye J, et al. The role of costing in the introduction and scale-up of HIV pre-exposure prophylaxis: evidence from integrating PrEP into routine maternal and child health and family planning clinics in western Kenya. Journal of the International AIDS Society. 2019;22 Suppl 4:e25296.

27. Ying R, Sharma M, Heffron R, Celum CL, Baeten JM, Katabira E, et al. Costeffectiveness of pre-exposure prophylaxis targeted to high-risk serodiscordant couples as a bridge to sustained ART use in Kampala, Uganda. Journal of the International AIDS Society. 2015;18(4 Suppl 3):20013.

28. Mangenah C, Nhamo D, Gudukeya S, Gwavava E, Gavi C, Chiwawa P, et al. Efficiency in PrEP Delivery: Estimating the Annual Costs of Oral PrEP in Zimbabwe. AIDS and behavior. 2021.

29. Wanga V, Peebles K, Obiero A, Mogaka F, Omollo V, Odoyo JB, et al. Cost of pre-exposure prophylaxis delivery in family planning clinics to prevent HIV acquisition among adolescent girls and young women in Kisumu, Kenya. PLoS One. 2021;16(4):e0249625.

30. Bekker LG, Rebe K, Venter F, Maartens G, Moorhouse M, Conradie F, et al. Southern African guidelines on the safe use of pre-exposure prophylaxis in persons at risk of acquiring HIV-1 infection. Southern African journal of HIV medicine. 2016;17(1):455.

31. UNAIDS. Country: Zambia 2016 [Available from: https://www.unaids.org/en/regionscountries/countries/zambia.

32. Republic of Zambia Ministry of Health. Zambia Consolidated Guidelines for Treatment \& Prevention of HIV Infection. 2018.

33. Claassen CW, Mumba D, Njelesani M, Nyimbili D, Mwango LK, Mwitumwa $\mathrm{M}$, et al. Initial implementation of PrEP in Zambia: health policy development and service delivery scale-up. BMJ open. 2021;11(7):e047017. 
medRxiv preprint doi: https://doi.org/10.1101/2021.12.18.21268023; this version posted December 19, 2021. The copyright holder for this preprint (which was not certified by peer review) is the author/funder, who has granted medRxiv a license to display the preprint in It is made available under a CC-BY-NC-ND 4.0 International license .

479 34. Claassen C, Mumba D, Njelesani M, Nyimbili D, Mwango L, Mubanga E, et 480 al., editors. First year of implementation of PrEP in Zambia: Service delivery roll481 out and scale-up. IAS 2019; 2019; Mexico City, Mexico.

482 35. Center for International Health E, and Biosecurity, Virology loH, MEDICINE 483 UOMSO. The UMB Community HIV Epidemic Model

484 Differentiated Prevention, Testing, and ART Delivery for 485 the General Population and Pregnant \& Breast-Feeding 486 Women and their Children in Zambia.

487 36. USAID. DREAMS: PARTNERSHIP TO REDUCE HIV/AIDS IN ADOLESCENT 488 GIRLS AND YOUNG WOMEN 2021 [Available from: 489 https://www.usaid.gov/global-health/health-areas/hiv-and-aids/technical490 areas/dreams.

491 37. Zambia Bo. Bank of Zambia Average Exchange Rates 2018 [Available from: 492 https://www.boz.zm/average-exchange-rates.htm.

493 38. Republic of Zambia Ministry of Health and National HIV/AIDS/STI/TB 494 Council. Implementation Framework \& Guidance For Pre-exposure Prophylaxis 495 of HIV Infection. 2018.

496 39. Nichols BE, Girdwood SJ, Shibemba A, Sikota S, Gill CJ, Mwananyanda L, 497 et al. Cost and Impact of Dried Blood Spot Versus Plasma Separation Card for 498 Scale-up of Viral Load Testing in Resource-limited Settings. Clinical infectious 499 diseases : an official publication of the Infectious Diseases Society of America. 500 2020;70(6):1014-20.

501 40. Case KK, Gomez GB, Hallett TB. The impact, cost and cost-effectiveness of 502 oral pre-exposure prophylaxis in sub-Saharan Africa: a scoping review of 503 modelling contributions and way forward. Journal of the International AIDS 504 Society. 2019;22(9):e25390.

505 41. Mutuku U, Forsythe, S., Glaubius, R., Were, D., Musau, A. Estimating the 506 Costs of PrE-exposure Prophylaxis (PrEP) in Ten Counties of Kenya. International 507 Conference for AIDS and STIs in Africa2019.

508 42. Peebles K, Mugwanya KK, Irungu E, Odoyo J, Wamoni E, Morton JF, et al. 509 Low costs and opportunities for efficiency: a cost analysis of the first year of 510 programmatic PrEP delivery in Kenya's public sector. BMC health services 511 research. 2021;21(1):823.

512 43. Roberts A, Barnabas, RV., Abuna, F., Lagat, H., Kinuthia, J., Pintye, J., 513 Bochner, A., Baeten, J., John-Stewart, G., Levine, C. The Cost of PrEP Delivery in 514 Kenyan Antenatal, Postnatal, and Family Planning Clinics. Conference on 515 Retroviruses and Opportunistic Infections; March 4-7 2019; Seattle, WA, 516 USA2019.

517 44. Guinness L, Kumaranayake L, Rajaraman B, Sankaranarayanan G, Vannela 518 G, Raghupathi P, et al. Does scale matter? The costs of HIV-prevention 
medRxiv preprint doi: https://doi.org/10.1101/2021.12.18.21268023; this version posted December 19, 2021. The copyright holder for this preprint (which was not certified by peer review) is the author/funder, who has granted medRxiv a license to display the preprint in It is made available under a CC-BY-NC-ND 4.0 International license .

519 interventions for commercial sex workers in India. Bulletin of the World Health

520 Organization. 2005;83(10):747-55.

521 45. Kumaranayake L. The economics of scaling up: cost estimation for 522 HIV/AIDS interventions. Aids. 2008;22 Suppl 1:S23-33.

523 46. Nichols BE, Girdwood SJ, Crompton T, Stewart-Isherwood L, Berrie L, 524 Chimhamhiwa $D$, et al. Monitoring viral load for the last mile: what will it cost? 525 Journal of the International AIDS Society. 2019;22(9):e25337.

526 47. Cham HJ, MacKellar D, Maruyama H, Rwabiyago OE, Msumi O, Steiner C, 527 et al. Methods, outcomes, and costs of a 2.5 year comprehensive facility-and 528 community-based HIV testing intervention in Bukoba Municipal Council, 529 Tanzania, 2014-2017. PLoS One. 2019;14(5):e0215654.

530 48. Meyer-Rath G, van Rensburg C, Chiu C, Leuner R, Jamieson L, Cohen S. The 531 per-patient costs of HIV services in South Africa: Systematic review and 532 application in the South African HIV Investment Case. PLoS One. 533 2019;14(2):e0210497.

534 49. Choko AT, Candfield S, Maheswaran H, Lepine A, Corbett EL, Fielding K.

535 The effect of demand-side financial incentives for increasing linkage into HIV 536 treatment and voluntary medical male circumcision: A systematic review and 537 meta-analysis of randomised controlled trials in low- and middle-income 538 countries. PLoS One. 2018;13(11):e0207263.

539 50. Larson BA, Bii M, Halim N, Rohr JK, Sugut W, Sawe F. Incremental 540 treatment costs for HIV-infected women initiating antiretroviral therapy during 541 pregnancy: A 24-month micro-costing cohort study for a maternal and child 542 health clinic in Kenya. PLoS One. 2018;13(8):e0200199.

543 51. UNAIDS. UNAIDS 2019 Report. 2019.

544 52. Nichols BE GS, Crompton T, Stewart-Isherwoodd L, Berried L, 545 Chimhamhiwa D, Moyo C, Kuehnleg J, Stevens W and Rosen S, for EQUIP Health. 546 Monitoring viral load for the last mile: what will it cost? 2019. 